\title{
EVALUATION OF CLASS TEACHERS' OPINIONS ON THE REMEDIAL PROGRAM IN PRIMARY SCHOOLS (RPPS)
}

\author{
Sevgi Balkan", \\ Coşkun Küçüktepe ${ }^{2 i}$ \\ ${ }^{1}$ Istanbul Univesity Cerrahpaşa, \\ Istanbul, Turkey \\ orcid.org/0000-0003-3239-4211 \\ 2ं̇stanbul University Cerrahpaşa, \\ Istanbul, Turkey \\ orcid.org/0000-0003-3908-964X
}

\begin{abstract}
:
The purpose of the current study is to evaluate the remedial program first implemented in primary schools in the 2018-2019 school year on the basis of teacher opinions. To this end, it is attempted to perform a holistic analysis of the opinions of the class teachers implementing the training program in their classes, its implementation stages, the grade levels covered by the program, the content of the book used in the implementation and its applicability, the place and time of the implementation and to provide some insights for future research. In the current study designed as a qualitative study, the purposive sampling method was used and thus, a total of 8 tenured teachers implementing this program in their classes were selected. A semi-structured interview form was prepared to collect data and the data collected through this semi-structured interview form were analysed by using the descriptive analysis and content analysis techniques. The findings obtained from the analysis of the data revealed that the teachers evaluated the general objectives of RPPS as positive, partially positive and negative. Although they did not receive any in-service training while implementing the program, they did not encounter a general problem, and implemented the program in line with the information given to them. The teachers expressed different opinions about the objectives of the program and generally stated that the program should be started from the second grade onwards. The teachers made different comments on the content of the source book prepared for the program according to different modules and gave positive and negative opinions about its applicability. The teachers arranged the implementation steps according to their own knowledge and experience; they found the school suitable for the place of implementation, but they put forward different opinions about the time of implementation. In addition, the teachers presented various ideas on the basis of their experiences during the implementation.
\end{abstract}

${ }^{i}$ Correspondence: email coskun.kucuktepe@iuc.edu.tr 
Keywords: remedial program, class teachers, primary school, RPPS

\section{Introduction}

Remedial programs refer to steps taken with the desire to move forward the education systems at both national and international levels, and not to leave students behind, when it is measured that the curriculum being implemented is not adequate for these students to accomplish the set objectives. When the works carried out in our country in particular and around the world in general while taking these steps are compared, it is understood that each country tries to take precautions in line with its own needs, assigning greater priority to language and mathematics skills.

Education programs plan for each student to leave the school with a competence required to solve real-life problems. When the studies conducted in this direction are examined, it is understood that various countries try to impart the basic knowledge and skills to their students before leaving school by implementing different programs. Since 2002, the United States has applied achievement tests covering the fields of reading and mathematics to all students starting from the third grade to the eighth grade every year, and according to the results obtained from these tests, it evaluates whether the students have reached the desired level (Woolfolk, 2015: 44).

In Germany, a reading program designed for students and families was put into practice in 2010, students and parents have been supported from the first years of education onwards both at school and home, and measures have been attempted to be taken for students having literacy problems. In addition, states have collaborated with universities in their regions to work for their students who need support in reading, writing and mathematics.

It is seen that different programs have been implemented in countries such as Austria, France, Northern Ireland, Romania, Portugal, Bulgaria, Slovenia, Estonia, Russia, Spain, Finland, Malta to help students overcome their learning deficiencies (Gençoğlu, 2019: 859-862). Especially in primary school age, students' achieving the desired goals is of vital importance in preparing the ground for their education in the following years, so in our country, various steps are taken at different times, at different levels, according to needs of students.

The remedial program, which was put into practice in primary schools with the cooperation of the General Directorate of Basic Education and UNICEF, was expanded towards the $3^{\text {rd }}$ and $4^{\text {th }}$ grades in different regions of the country in the 2017 - 2018 school year and was implemented in the whole country in the 2018 - 2019 school year. Starting from the 2019-2020 school year, the remedial program, which excluded $4^{\text {th }}$ grade students and applied only to $3^{\text {rd }}$ grade students, was developed in five parts; its purpose, scope and basis; general objectives, principles; commissions to be established, their duties, authorities, responsibilities, supervision; implementation process, student attendance, the books and files to be kept; various and final provisions and is explained in sections in the Ministry of National Education Primary Schools Directive (MEB, 2018). 
When the general features of the program are examined, it is seen that it aims to help students taken into the scope of the program to accomplish the objectives set in the learning areas of language skills and natural numbers and four operations performed with natural numbers. The general goals of the program are to plan learning experiences with activities that will enable students to achieve the objectives deemed appropriate within the scope of RPPS in Turkish and mathematics lessons, to provide psychosocial support, to prevent adaptation problems that may occur in further levels of education, to increase their school attendance, to help students who participate in the program reach the targeted learning level and to contribute to the training of individuals who have been able to self-actualize. In line with these general goals, specific goals have been determined to improve students' language and mathematical literacy skills.

Students who do not need special education, who have not achieved the expected objectives within the program at the desired level, children of immigrant and seminomadic, refugee families, children under temporary protection, children of families engaged in seasonal agricultural work are the target audience of this program, and by using the tools prepared by the Ministry of National Education to identify the students to be admitted to the program, the students have been selected to the program. When the general structure of this program is examined, it is seen that it consists of three areas: Turkish, mathematics and psychosocial support (MEB, 2019). The modules, learning areas / sub-learning areas, the number of objectives and class hours for the Turkish and mathematics courses are given in Table 1 .

As can be seen in Table 1, there are three modules determined for the courses of Turkish and mathematics each. For the Turkish course, there are a total of 16 objectives covering the learning areas of listening / watching, writing and speaking while for the mathematics course, there are a total of 22 objectives covering the learning areas of natural numbers, addition, subtraction, multiplication and division. When the modules are considered separately, it is seen that there are 13 objectives in the Module 1 of the Turkish and mathematics courses together, 17 objectives in the Module 2 of the Turkish and mathematics courses together, and 8 objectives in the Module 3 of the Turkish and mathematics courses together and a total of 96 class hours are allocated to the Turkish course and 64 class hours are allocated to the mathematics course. In the Module 2 of the Turkish course, there are 10 objectives to which a total of 72 class hours are allocated and nearly half of 160 class hours are allocated to reading and writing. 
Table 1: The Courses Taught in RPPS, Modules, Learning Areas /

Sub-Learning Areas, the Number of Objectives / Class Hours

\begin{tabular}{|c|c|c|c|c|c|c|c|}
\hline 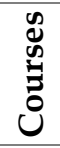 & Modules & $\begin{array}{l}\text { Listening / } \\
\text { Watching }\end{array}$ & Reading & Writing & Speaking & $\begin{array}{c}\text { Number of } \\
\text { Objectives } \\
\text { Total }\end{array}$ & $\begin{array}{l}\text { Class } \\
\text { Hours }\end{array}$ \\
\hline \multirow{4}{*}{ 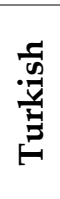 } & Module 1 & 2 & 0 & 0 & 1 & 3 & 5 \\
\hline & Module 2 & 1 & 4 & 5 & 0 & 10 & 72 \\
\hline & Module 3 & 0 & 2 & 1 & 0 & 3 & 19 \\
\hline & Total & 3 & 6 & 6 & 1 & 16 & 96 \\
\hline \multirow{5}{*}{ 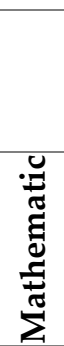 } & & $\begin{array}{c}\text { Natural } \\
\text { Numbers }\end{array}$ & $\begin{array}{l}\text { Addition / } \\
\text { Substraction }\end{array}$ & \multicolumn{2}{|c|}{$\begin{array}{l}\text { Multiplication / } \\
\text { Division }\end{array}$} & $\begin{array}{c}\text { Number of } \\
\text { Objectives } \\
\text { Total }\end{array}$ & $\begin{array}{l}\text { Class } \\
\text { Hours }\end{array}$ \\
\hline & Module 1 & 4 & 6 & \multicolumn{2}{|c|}{0} & 10 & 24 \\
\hline & Module 2 & 3 & 4 & \multicolumn{2}{|c|}{0} & 7 & 24 \\
\hline & Module 3 & 0 & 0 & \multicolumn{2}{|c|}{5} & 5 & 16 \\
\hline & Total & 7 & 10 & \multicolumn{2}{|c|}{5} & 22 & 64 \\
\hline
\end{tabular}

The class hours are organised to be a total of 10 hours a week, either being two class hours a day on weekdays or five class hours each day at the weekend. After determining the teachers who will implement the program, it has been found appropriate for each student to attend the program in his/her own school. The program is a free remedial program designed to help students complete the subjects they are lacking.

\section{Purpose of the Study}

In the current study, it was aimed to evaluate class teachers' opinions about the remedial program implemented in primary schools. Answers to the following research questions were sought;

1) What are your opinions about the general goals of RPPS started to be implemented in primary schools?

2) What are your experiences you have had while implementing the program?

3) Have you had any in-service training about RPPS (stages of implementation, eschool procedures, etc.)? If you have, what are your opinions about this in-service training?

4) What do you think about the objectives of RPPS?

5) What are your opinions about the target audience of RPPS?

6) What are your opinions about the content of the book prepared for the program?

7) What are your opinions about the applicability of the book prepared for the program?

8) What are your opinions about the program's place and time of implementation? 


\section{Method}

\subsection{Research Model}

As the current study aimed to determine class teachers' opinions, it was designed as a qualitative research. The general aim of qualitative research can be defined as "to develop a perception of how people make sense of their lives, to reveal the outlines of this process and to describe their way of interpreting their experiences" (Merriam, 2015: 14). Thus, it was decided to use the qualitative research method in the current study aiming to reveal the outlines of the process on the basis of class teachers' experiences regarding RPPS and to understand their way of interpreting their experiences.

\subsection{Participants}

The participants of the current study are 8 tenured class teachers voluntarily implementing RPPS in state schools located in the Saryyer district of the city of İstanbul in the 2018-2019 school year. Some demographic information about the participants is given in Table 2.

As can be seen in Table 2, 7 of the participating teachers are females and 1 is male; 6 are graduates of elementary school teaching while 1 is a graduate of chemistry teaching and 1 is a graduate of biology teaching but all of them are working as class teachers. While 5 of the teachers are teaching $3^{\text {rd }}$ and $4^{\text {th }}$ graders, 2 are teaching $1^{\text {st }}$ graders and 1 is teaching $2^{\text {nd }}$ graders. All the teachers have at least 12 years of teaching experience. The teachers have been working for at least two years in their current school. The teachers taught different modules. The number of students involved in the program changes depending on the module. Due to the ethical principles taken into consideration in the current study, the names of the participating teachers in the interviews were not given; rather they were coded as T1, T2.

Table 2: Some Demographic Information about the Participants

\begin{tabular}{|c|c|c|c|c|c|c|c|}
\hline Participants & Gender & Branch & $\begin{array}{l}\text { Grade Level } \\
\text { Instructed }\end{array}$ & $\begin{array}{l}\text { Length } \\
\text { of } \\
\text { Service }\end{array}$ & $\begin{array}{c}\text { Length of } \\
\text { Service in } \\
\text { the Current } \\
\text { School }\end{array}$ & $\begin{array}{l}\text { Module } \\
\text { Instructed }\end{array}$ & $\begin{array}{c}\text { Number } \\
\text { of } \\
\text { Students }\end{array}$ \\
\hline \multirow{2}{*}{$\mathrm{T} 1$} & \multirow{2}{*}{ Female } & \multirow{2}{*}{$\begin{array}{l}\text { Class } \\
\text { Teacher }\end{array}$} & \multirow{2}{*}{$4^{\text {th }}$ Grade } & \multirow{2}{*}{14} & \multirow[t]{2}{*}{ 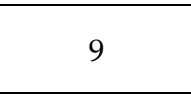 } & Turkish Module 3 & 10 \\
\hline & & & & & & Math Module 3 & 10 \\
\hline \multirow{4}{*}{$\mathrm{T} 2$} & \multirow{4}{*}{ Female } & \multirow{4}{*}{$\begin{array}{l}\text { Class } \\
\text { Teacher }\end{array}$} & \multirow{4}{*}{$1^{\text {st }}$ Grade } & \multirow{4}{*}{34} & \multirow{4}{*}{31} & Math Module 1 & 1 \\
\hline & & & & & & Math Module 2 & 10 \\
\hline & & & & & & Math Module 3 & 10 \\
\hline & & & & & & Turkish Module 3 & 1 \\
\hline \multirow{4}{*}{$\mathrm{T} 3$} & \multirow{4}{*}{ Male } & \multirow{4}{*}{$\begin{array}{l}\text { Class } \\
\text { Teacher }\end{array}$} & \multirow{4}{*}{$1^{\text {st }}$ Grade } & \multirow{4}{*}{29} & \multirow{4}{*}{3} & Turkish Module 1 & 1 \\
\hline & & & & & & Turkish Module 2 & 3 \\
\hline & & & & & & Turkish Module 3 & 4 \\
\hline & & & & & & Math Module 3 & 4 \\
\hline \multirow{4}{*}{$\mathrm{T} 4$} & \multirow{4}{*}{ Female } & \multirow{4}{*}{$\begin{array}{l}\text { Class } \\
\text { Teacher }\end{array}$} & \multirow{4}{*}{$3^{\text {th }}$ Grade } & \multirow{4}{*}{16} & \multirow{4}{*}{2} & Math Module 1 & 10 \\
\hline & & & & & & Math Module 2 & 10 \\
\hline & & & & & & Math Module 3 & 10 \\
\hline & & & & & & Turkish Module 3 & 5 \\
\hline
\end{tabular}


ON THE REMEDIAL PROGRAM IN PRIMARY SCHOOLS (RPPS)

\begin{tabular}{|l|l|l|c|c|c|c|c|}
\hline \hline T5 & Female & $\begin{array}{l}\text { Class } \\
\text { Teacher }\end{array}$ & $4^{\text {th }}$ Grade & 14 & 10 & Math Module 3 & 6 \\
\hline T6 & Female & Chemistry & $4^{\text {th }}$ Grade & 20 & 4 & Turkish Module 3 & 7 \\
\hline T7 & Female & Biology & $2^{\text {nd }}$ Grade & 26 & 2 & Math Module 2 & 10 \\
\hline T8 & Female & $\begin{array}{l}\text { Class } \\
\text { Teacher }\end{array}$ & $3^{\text {th }}$ Grade & 12 & 7 & Turkish Module 3 & 10 \\
\hline
\end{tabular}

\subsection{Data Collection}

In the current study, the interview and document analysis methods were employed to collect data. In the interviews conducted with the teachers, a semi-structured interview form was used. While preparing this form, the RPPS directive and application guideline were taken as the basis and the opinions of 2 experts and 2 class teachers having participated in the implementation of the program were sought. A total of 8 semistructured open-ended questions were directed to the 8 classroom teachers who were implementing the program, and all responses were recorded. At the end of each interview, confirmation was obtained from the teacher who participated in the interview that the data obtained were correct. The teachers stated that they participated in the study voluntarily and that the answers in the records belonged to them.

\subsection{Data Analysis}

In this study, descriptive analysis and content analysis were used for data analysis. The data obtained from the descriptive analysis are summarized and interpreted in accordance with the themes determined before the research (Yıldırım and Şimşek, 2018: 256). In the current study, the data derived from the opinions of the class teachers who participated in the study were summarized and interpreted in accordance with the themes.

\section{Findings}

The current study is grounded on the opinions of the class teachers having been involved in the implementation of RPPS, which was implemented as a pilot for the first time in the 2017 - 2018 school year and was started to be implemented across the whole country in the 2018 - 2019 school year. The data of the study are collected with the open-ended questions asked to the teachers, the findings are presented in tables and supported with the quotations from the teachers' statements.

\subsection{Findings Related to the Teachers' Opinions about the General Goals of RPPS}

In order to find an answer to the first research question, the opinions of the participating teachers were asked about the goals of the program and some teachers stated that they found them positive; some others stated that they found them partially positive and the remaining teachers stated that they found them negative. The related findings are presented in Table 3. 
Table 3: Findings related to the Teachers' Opinions about the General Goals of RPPS

\begin{tabular}{|l|l|l|c|}
\hline Theme & Codes & $\mathbf{n}$ & Teacher Codes \\
\hline \multirow{4}{*}{ General Goals } & Positive & 3 & T1, T6, T7 \\
\cline { 2 - 4 } & Partially Positive & 2 & T3, T8 \\
\cline { 2 - 4 } & Negative & 3 & T2, T4, T5 \\
\hline
\end{tabular}

As can be seen in Table 3, 3 of the participating teachers evaluated the program positively, 2 of them evaluated partially positively and 3 of them evaluated negatively. Below are given samples to the opinions of teachers finding the program positive, partially positive and negative: T1: "RPPS was a program developed to help students lagging behind. The program was developed to help $1^{\text {st }}$ or $2^{\text {nd }}$ graders not being able to catch up with the content covered by the curriculum. The aim was to improve the student, to improve in the subjects in which he/she lagged behind, both in Turkish and in mathematics. It was done for this purpose. I think it is positive." T6: "I find it useful; that is, the general goals." T7: "The main purpose of these general goals is to give remedial education to students who cannot master the objectives set in the curriculum in the school. I think it is positive; giving a second change to students to study the subjects in which they lagged behind. I can say that I find this initiation positive." T3: "General goals are good but there are problems in practice. What is aimed seems to be different from what is happening. Teachers are doing their best. I think it is partially positive." T8: "When you consider the general goals, it seems to be good to me but (...) these general goals should find reflection in practice. I can say that it is partially positive but goals cannot be accomplished completely in practice." T2: "When children come back to their mainstream classes, they are again in the same environment. There is no integrity. Because you give this education to these students as they need individual education; the starting point is reasonable but it remains uncompleted; you are trying to give something to these children for them to catch up with their $3^{\text {rd }}$ grade peers in a separate place; you steal their time and energy but then they cannot use what has been given to them. I cannot find it very useful." T4: "It was originally intended to support the children lagging behind, but it was not very efficient because the children were indifferent; I think the result is not very good because of the children. (...) Children who were not interested in lessons in their mainstream classes did not very actively participate in the after-school studies, as they were not interested in RPPS. It wasn't useful for them. I evaluate it negatively." T5: "RPPS seems to have been intended for good things but I don't think that it is a solution. It was intended for children, but it seems as if it was imposed by an external authority. It is not to serve a purpose; it is like other projects. Something done just for the sake of doing something."

\subsection{Findings Related to the Teachers' Opinions about the Experiences Lived during the Implementation of the Program}

In order to find an answer to the second research question, the opinions of the participating teachers were asked about the experiences they lived during the implementation of the program and the findings derived from the opinions of the teachers about their experiences are given in Table 4 . 
Table 4: Findings related to the Teachers' Opinions about the Experiences Lived during the Implementation of the Program

\begin{tabular}{|l|c|c|}
\hline Themes & $\mathbf{n}$ & Teacher Codes \\
\hline The program wasn't structured well. & 2 & T1, T3 \\
\hline $\begin{array}{l}\text { Problems have been experienced in the inclusion of 3rd and } 4^{\text {th }} \text { graders in } \\
\text { the same class. }\end{array}$ & 5 & T1, T3, T4, T6, T8 \\
\hline $\begin{array}{l}\text { Nor knowing what the learning problems of the students are is a serious } \\
\text { difficulty. }\end{array}$ & 1 & T2 \\
\hline $\begin{array}{l}\text { As the students that should be included in the Individualized Training } \\
\text { Program could not be identified, their inclusion in the program caused } \\
\text { problems. }\end{array}$ & 3 & T2, T3, T4 \\
\hline $\begin{array}{l}\text { The incompliance of RPPS with the implemented curriculum caused } \\
\text { problems. }\end{array}$ & 4 & T2, T3, T4, T7 \\
\hline The high number of students in the class is a problem. & 1 & T4 \\
\hline The time allocated for the teaching of modules caused problems. & 6 & T1, T4, T5, T6, T7, T8 \\
\hline There was a problem of attendance. & 2 & T4, T7 \\
\hline $\begin{array}{l}\text { The differences between the levels of students in the same module caused } \\
\text { problems. }\end{array}$ & 5 & $\mathrm{~T} 1, \mathrm{~T} 3, \mathrm{~T} 5, \mathrm{~T} 6, \mathrm{~T} 8$ \\
\hline Indifference of the families caused problems. & 4 & $\mathrm{~T} 2, \mathrm{~T} 4, \mathrm{~T} 5, \mathrm{~T} 8$ \\
\hline $\begin{array}{l}\text { Teachers' lack of willingness to participate in the program caused } \\
\text { problems. }\end{array}$ & 4 & $\mathrm{~T} 1, \mathrm{~T} 2, \mathrm{~T} 3, \mathrm{~T} 5$ \\
\hline
\end{tabular}

As can be seen in Table 4, two of the participating teachers stated that the program wasn't structured well. T1: "The program was not structured well because in my classroom, there were both $3^{\text {rd }}$ graders and $4^{\text {th }}$ graders, and students with different levels of academic achievement." T3: "We used to write the plans by hand, but we were allowed to make changes according to the conditions we were in and the teacher who prepared the plan could change it according to the situation of his/her class. There are now restrictions. I did not find the infrastructure of this program appropriate." Five teachers (T1, T3, T4, T6, T8) thought that the presence of $3^{\text {rd }}$ graders and $4^{\text {th }}$ graders in the same class is a problem. T1: "In my opinion, $4^{\text {th }}$ graders should be in one class while $3^{\text {rd }}$ graders should be in one class." T3: "There are activities requiring cutting, gluing and colouring and they are not suitable as $3^{\text {rd }}$ and $4^{\text {th }}$ graders are together in one class. These can be activities needed by $3^{\text {rd }}$ graders but absolutely unnecessary for $4^{\text {th }}$ graders. The classes should be separated." T4: "All the problematic students come together and this is a serious problem. There is a chaos; as they are not students quietly sitting and listening to the teacher in the class. It is a big mistake to bring $3^{\text {rd }}$ and $4^{\text {th }}$ graders together." T6: "Children came from different classes and different grade levels. I think this should be changed." T8: "I think $3^{\text {rd }}$ and $4^{\text {th }}$ graders should be separated. I have realized that the needs are different in practice. They should not be in the same class." T2 found not knowing students' learning problems as a serious difficulty; "The problem here is not about just education and instruction; there are other problems. There are many causes of their failure to learn. These children should be analysed in more detail. It should be found why they cannot learn then the required efforts can be made to solve it by the class teacher, parents." Three teachers (T2, T3, T4) stated that inclusion of the students who would normally be in an Individualized Education Program in RPPS as they could not be identified is a problem. T2: "I am teaching the $3^{\text {rd }}$ grade curriculum, but the 
students do not have enough capacities, potential and energy to follow this curriculum. Teachers are directing them; our parents do not want to send their children for the fear of their children's being stigmatized. The problems of these children should have been diagnosed well; they had educational problems, but their parents did not care about this." T3: "... we are sending children to the counselling teacher, but parents do not want their children to be diagnosed. Thus, they come to RPPS although they should be in an individualized education program." T4: There are even parents not sending their children even though they are referred to individualized education. As a result, they come to this program." Four teachers (T2, T3, T4, T7) found the incompliance with RPPS and the implemented curriculum as a problem. T2: "... when these children go to their mainstream classes, they will continue studying the curriculum and as a result, they will lag behind again. For example, we worked on problem solving here and they continue studying fractions in their mainstream classes. "T3: "As we follow the book here, we have to follow a different sequence. As a result, we cover different subjects and we cannot catch up with the curriculum followed in mainstream classes. This is difficult for these children; difficult for the teacher working in RPPS and difficult for the teacher in their mainstream class. There should be better coordination between the two programs." T4: "... while we were studying multiplication in the mainstream class, we studied addition in RPPS and as a result, the children got confused. There is no consistency between the subjects studied in these different classes and this has caused some problems. Some children reacted to this as they were studying addition here while they were studying multiplication in their mainstream classes. Their mainstream class teachers are also complaining about this inconsistency. " T7: "... there should be a better compliance between the curriculum and the RPPS program. If there was a better coordination between the subjects studied in the classes, then the program would be more efficient." One teacher (T4) stated that the higher number of students in the class is a problem; "But there were just 5 students in the Turkish Module 3 and it was ideal. When the number of students is small, then you can better involve them in the lesson. When there were 10 students in the math class, it was really difficult." Six teachers (T1, T4, T5, T6, T7, T8) found the time allocated to the modules as a problem; T1: "There are too many subjects to be covered in the Turkish module and just 15 class hours are allocated to it, it is not possible to study this module within 15 class hours. I am talking about Module 3. More time should be allocated. I think 15 class hours are not adequate." T4: "Time allocated to the modules is not enough." T5: "We have just 14 hours to have students achieve the objectives set for the subjects that should be covered within four years. They contradict themselves. Because they want me to impart the objectives and learning outcomes that should normally be imparted within a four-year period just within 14 hours; how can I do this?" T6: "They should be like the remedial courses in the middle school. There should be continuity. We should not restrict the instruction with certain time limits such as 15, 60 or 40 class hours if there is no financial burden on the shoulder of families. Moreover, the students in the target audience are children for whom learning takes more time. They have learning difficulties. You are teaching today, and they forget the next day. In my opinion, there should be more continuity. "T7: "I found the time allocated to the Module 2 in mathematics inadequate." T8: "As the main focus was on reading comprehension, the time was inadequate." T4 and T7 stated student absenteeism as a problem. T4: "I started teaching with the Module 1 and continued up to the end of the Module 3 
and when the time passed, they gave up attending the lessons. The children got bored in the middle of the Module 2 and there were many students not attending the lessons covering the Module 3." T7:"With the time progressing, the number of students attending the lessons dropped and also the performance and interest of the students attending the lessons decreased as well. There were some students who got sick due to changing seasonal conditions and as a result, there were some students whose attendance dropped." Five teachers (T1, T3, T5, T6, T8) found different levels of students taking the same module as a problem. T1: "For example, there was a group of students who could not comprehend what they were reading; there were students in one group who could not read and write. It was a class of mixed ability group. Students with different levels of achievement were gathered in the same class. Therefore, I experienced some problems." T3: "Each child has a different capacity. For example, a subject learned by one child within an hour can be learned by another in an hour and half, or 2 hours. The levels of the children were different."T5: "There were serious differences between the levels of the students and this made it difficult for some students to catch up with their peers." T6: "There were $3^{\text {rd }}$ and $4^{\text {th }}$ graders and their levels of achievement were different. There can be differences even between the students who were born in the same year." T8: "The children had problems at different levels, but we educated them in the same module. This was challenging." Four teachers (T2, T4, T5, T8) stated the indifference of families as a problem. T2: "The family's indifference and its perception of education resulted in their children's lagging behind." T4: "Family support is a must. Students think that it is extra, so they get bored after a while. We asked the parents whether they would allow their children to take part in the program. There were some parents not allowing their children to take part in the program. Some parents of the children who really needed this program did not allow them. If the parents of these children had been more interested, the children would be more successful. Moreover, there are working parents. There is nobody to take the child from the school at that time; thus, he/she comes by bus. There are parents who can send their children to this program, but they don't. You do not have to pay anything extra; the state provides such an opportunity for you, so you should send your children. This really makes me surprised; you are given such an opportunity, but you do not make use of this. Education starts from the family." T5: "In education, not just the child but the family is also very important and their economic conditions are very important." T8: "It is clear that there is not enough interest in the family. If the child is supported by the family, then the teacher can do better. That is, as the family does not care about it, children do not do what they should do at home and as a result they are in this program now. In fact, they are not bad students." Four teachers (T1, T2, T3, T5) stated the unwillingness of teachers to work in the program as a problem. T1: "I accepted as it was just 15 class hours; in fact, I did not have time, the school director requested and I had to accept as they could not find any teacher willing to work in the program and I started in this way unfortunately." T2: "As you are not paid much for teaching in RPPS, nobody accepted to work there, so I had to accept it." T3: "Teachers did not want to work in the program and although I was teaching $1^{\text {st }}$ graders, who were really difficult to deal with, I had to accept it." T5: "It was just one day a week and it was quite enjoyable at first but then it became 14 class hours and got really boring. I started this not for money because it is paid very little. It is not a work to be done for financial satisfaction. Therefore, nobody wanted to work in this program. " 


\subsection{Findings Related to the Teachers' Opinions about the In-service Training they Received within the Scope of RPPS}

In order to find an answer to the third research question, the teachers were asked whether they had received any in-service training within the scope of RPPS and the responses given by the teachers are given in Table 5 .

Table 5: Teachers' Opinions about the In-service

Training they Had Received within the scope of RPPS

\begin{tabular}{|l|c|c|c|}
\hline Themes & Codes & $\mathbf{n}$ & Teacher Codes \\
\hline I received in-service training & No & 8 & T1, T2, T3, T4, T5, T6, T7, T8 \\
\hline I was informed by the school administration & Yes & 1 & T4 \\
\cline { 2 - 4 } & No & 7 & Ö1, Ö2, Ö3, Ö5, Ö6, Ö7, Ö8. \\
\hline \multirow{2}{*}{ I was given a guideline } & Yes & 4 & T1, T4, T5, T6 \\
\cline { 2 - 4 } & No & 4 & T2, T3, T7, T8 \\
\hline
\end{tabular}

As can be seen in Table 5, the participating teachers did not receive any in-service training. Only 1 teacher stated that he/she was informed by the school administration while 7 of them stated that they were not informed by the school administration. Four of the teachers stated that they were given a guideline while the other 4 stated that they were not given a guideline. T1: "I have not received any training. That is, no training has been given within the context of RPPS. They gave a guideline, I know it, but we haven't been given any training. T2: "I haven't received any training; I knew that an exam would be taken by the students before and after the program, but I didn't make any exam." T3: "No I haven't received any training." T4: "No, I haven't received. I just examined the guideline given by the school administration. The school administration held some meetings about it and we got the required information there." T5: "No I haven't received. Yet, we were already given the teacher guideline and a book for students. We were given the guideline. There are the subjects to be taught in the book. Which modules are taught is determined as a result of an exam taken by students for the purpose of determining what is missing in students. We were given our guidelines and the exam results of the students in our class and then we started to teach in line with this information but before this we made use of our professional experience." T6: "No, I haven't received, there is only the guideline." T7: "No, I haven't received, what I have drawn on up to now is my professional experience. I looked into the objectives of the program or I got information from the administration when necessary. I learned through my own efforts and used my professional experience; we are already doing similar things in our mainstream classes. For example, after you have determined in which point of a math operation, either being addition, subtraction, multiplication or division, the student has a problem, it is easy to correct the problem. I did not have any information about RPPS but one day an official document came to school and then the program started. I did not get a guideline from anyone." T8: "No, I haven't received. Nobody gave me information or a guideline." 


\subsection{Findings Related the Teachers' Opinions about the Objectives of RPPS}

In order to find an answer to the fourth research questions, the teachers were asked their opinions about the objectives of RPPS. The teachers' opinions are presented in Table 6.

Table 6: Findings related to the Teachers' Opinions about the Objectives of RPPS

\begin{tabular}{|l|l|c|c|}
\hline Themes & Codes & $\mathbf{n}$ & Teacher Codes \\
\hline \multirow{2}{*}{$\begin{array}{l}\text { Objectives of the Turkish } \\
\text { Course }\end{array}$} & Adequate & 3 & $\mathrm{~T} 2, \mathrm{~T} 4, \mathrm{~T} 8$ \\
\cline { 2 - 4 } & Inadequate & 3 & $\mathrm{~T} 1, \mathrm{~T} 3, \mathrm{~T} 6$ \\
\hline \multirow{2}{*}{$\begin{array}{l}\text { Objectives of the Mathematics } \\
\text { Course }\end{array}$} & Adequate & 2 & $\mathrm{~T} 4, \mathrm{~T} 7$ \\
\cline { 2 - 4 } & Inadequate & 4 & $\mathrm{~T} 1, \mathrm{~T} 2, \mathrm{~T} 3, \mathrm{~T} 5$ \\
\hline
\end{tabular}

As can be seen in Table 6, the objectives are separated as the objectives of the Turkish course and the objectives of the mathematics course. Three of the teachers found the objectives of the Turkish course adequate while 3 of the teachers found them inadequate. On the other hand, 2 of the teachers found the objectives of the mathematics course adequate while 4 of the teachers found them inadequate. The opinions of the teachers about the objectives of the Turkish course are as follows: T1: "The objectives are not suitable for the level of the students. For a student not knowing how to read and write, the objectives are not suitable. "T2: "The objectives are enough for the Turkish course." T3: "I found the objectives of the Turkish course inadequate." T4: "The objectives are good; this is for students with low academic achievement, so the objectives are not too many for them. They are adequate, it is good that they are not exaggerated." T6: "More different objectives can be included in the Module 3. More grammar, synonyms, homophones would have been included; they could write only short texts, comprehend what they read, so they could have gone further." T8: "The objectives were adequate. Because in the Module 3, which I instructed, there were many activities conducted to improve reading comprehension; we did many activities on reading comprehension. There occurred certain progress in the children." The opinions of the teachers about the objectives of the mathematics course are as follows: T1: "The objectives set in the mathematics course are for children who do not know any mathematics. But, the problem was that there were children who could not perform a four-digit addition operation but also there were children who could not perform any addition operations in RPPS. Therefore, the objectives were not helpful for all the children." T2: "There were objectives focused on natural numbers, how to read and write numbers but factions could have also been included or some geometry. I did not find them adequate." T3: "Objectives should vary depending on the capacity of each child because each child has a different phase of learning. It could have been designed better; I can say that they are inadequate." T4: "If the instruction was one-to-one in RPPS, then it would be more useful for children. I observed that the students who regularly attended the lessons and actively participated in them showed a good progress especially in mathematics. They were adequate." T5: "I think that they are not enough in that these children learn hard and forget easily. When you have come to the subject you taught one week ago you see that they have forgotten it." T7: "As the level and deficiencies of the children were already known, they received education in line with their needs. They are suitable objectives because they are also focused on in the mainstream classes of these children. Thus, if they cannot achieve these objectives in their mainstream classes, then they can have a second chance to achieve 
them here. For example, if the child could not learn addition and subtraction then we tried to teach him/her this in this program with many activities. They were adequate for the students who were unsuccessful in their mainstream classes."

\subsection{Findings Related to the Teachers' Opinions about the Target Audience of RPPS}

In order to find an answer to the fifth research question, the teachers were asked their opinions about the target audience of RPPS and the findings derived from these opinions are presented in Table 7.

Table 7: Findings related to the Teachers' Opinions about the Target Audience of RPPS

\begin{tabular}{|l|c|c|}
\hline Themes & $\mathbf{n}$ & Teacher Codes \\
\hline It should be implemented in all the grade levels & 2 & $\mathrm{~T} 3, \mathrm{~T} 7$ \\
\hline It should be started from the $2^{\text {nd }}$ grade level & 4 & $\mathrm{~T} 1, \mathrm{~T} 2, \mathrm{~T} 4, \mathrm{~T} 6$ \\
\hline It would be suitable to be implemented in the $3^{\text {rd }}$ grade level & 1 & $\mathrm{~T} 5$ \\
\hline It would be suitable to be implemented in the $3^{\text {rd }}$ and $4^{\text {th }}$ grade levels & 1 & $\mathrm{~T} 8$ \\
\hline
\end{tabular}

As can be seen in Table 7, 2 of the teachers stated that RPPS should be implemented in all the grade levels while 4 of the teachers stated that it should be started from the $2^{\text {nd }}$ grade level. One of the teachers stated that it would be suitable to be implemented in the $3^{\text {rd }}$ grade level and 1 teacher stated that it would be suitable to be implemented in the $3^{\text {rd }}$ and $4^{\text {th }}$ grade levels. T1: "In my opinion, it is a program that should be started to be implemented from the $2^{\text {nd }}$ grade. The earlier the intervention is, the better it is." T2: "the $3^{\text {rd }}$ grade is too late. All children know reading and writing when they are in the middle of the $2^{\text {nd }}$ grade and if they do not, they are easily recognized. Therefore, I want it to be started from the $2^{\text {nd }}$ grade level onwards." T3: "In fact, it should be implemented in all the grade levels. In my opinion, RPPS is not much different from the Individualized Education Program. Actually, children should always be supported not only in the $3^{\text {rd }}$ and $4^{\text {th }}$ grades. Children should be supported in all the grades according to their special conditions so that they would not get lost within the education system. I could be difficult in the $1^{\text {st }}$ grade; therefore, it should be started from the $2^{\text {nd }}$ grade onwards. The earlier it starts, the better it will be. T4: "Staring from the $2^{\text {nd }}$ grade seems to be quite reasonable. If they are accepted to this program when they are $2^{\text {nd }}$ graders, they can be more ready for and attain greater efficiency from the program when they are $3^{\text {rd }}$ graders." T5: "I think the $3^{\text {rd }}$ grade would be most suitable for it. Children who lagged behind in the $1^{\text {st }}$ and $2^{\text {nd }}$ grades can recover in the $3^{\text {rd }}$ grade because subjects taught in the $3^{\text {rd }}$ grade are largely repetitions of the subjects taught in the $1^{\text {st }}$ and $2^{\text {nd }}$ grades. If the child cannot close the gap in the $3^{\text {rd }}$ grade, then $4^{\text {th }}$ grade would be too late; thus, the 3rd grade seems to be ideal to start it." T6: "I think that it should be started from the $2^{\text {nd }}$ grade because the Module 1 and Module 2 are focused on teaching reading and writing; that is, on the spelling and pronunciation of letters and sounds so this would not be suitable for the $3^{\text {rd }}$ grade so I think it should be started from the second grade." T7: "The target audience of the program is $3^{\text {rd }}$ or $4^{\text {th }}$ graders. But it can also be used with $1^{\text {st }}$ and $2^{\text {nd }}$ graders. I have seen similar programs in private schools, giving extra support for children lagging behind. Such support programs can be implemented in state schools. The teacher can evaluate the students in his/her class and then refer the ones having some shortcomings to RPPS. T8: "I think the $3^{\text {rd }}$ and $4^{\text {th }}$ grades 
would be suitable for this program; how can these objectives be accomplished by students who do not even know reading and writing. Moreover, an exam should not be given to select the children for the program; teachers already know the students who lag behind in their classes so teachers can refer students to this program. It can be stressful for $2^{\text {nd }}$ graders. Therefore, it would be suitable for the $3^{\text {rd }}$ and $4^{\text {th }}$ graders."

\subsection{Findings Related to the Teachers' Opinions about the Content of the Source Book Used in RPPS}

In order to find an answer to the sixth research question, the teachers were asked their opinions about the content of the source book prepared for RPPS and the findings derived from these opinions are given in Table 8.

Table 8: Findings related to the Teachers' Opinions about the Content of the Source Book Prepared for RPPS

\begin{tabular}{|l|l|c|c|c|}
\hline Themes & Modules & Codes & n & Teacher Codes \\
\hline \multirow{3}{*}{$\begin{array}{l}\text { Source Book for the } \\
\text { Turkish Course }\end{array}$} & Modules 1 and 2 & Inadequate Content & 1 & T3 \\
\cline { 2 - 5 } & Module 3 & Inadequate Content & 4 & T1, T2, T3, T6 \\
\cline { 2 - 5 } & Module 3 & Inadequate Content & 1 & T4 \\
\hline \multirow{3}{*}{$\begin{array}{l}\text { Source Book for } \\
\text { the Mathematics Course }\end{array}$} & Module 1 & Adequate Content & 1 & T4 \\
\cline { 2 - 5 } & Modules 1 and 2 & Inadequate Content & 1 & T2 \\
\cline { 2 - 5 } & Module 2 & Adequate Content & 2 & T4, T7 \\
\cline { 2 - 5 } & Module 2 & Adequate Content & 3 & T4, T5, T8 \\
\cline { 2 - 5 } & Module 3 & Inadequate Content & 3 & T1, T2, T3 \\
\hline
\end{tabular}

As can be seen in Table 8, the teachers used the words adequate, inadequate and heavy to define the content of the source books prepared for the Turkish and mathematics courses. The teachers' opinions about the content of the source books are as follows: T1: "The book prepared for the Module 3 is like the $1^{\text {st }}$ grade Turkish textbook and its content would be more suitable for the Module 1. T2: "Light. There could be more details. More examples would be given. There would be more questions. I found it light; it is quite mediocre." T3: "...lack of emphasis on some subjects, leaving it to the discretion of the teacher... the content is inadequate and too simple." T4: "As the content in the Module 3 of the Turkish is too heavy for the children, I could not use it. But the content of the book prepared for mathematics is good." T5: "As the content is suitable for the levels of students and the book is not very challenging for students, I think it was good for them to feel satisfied." T6: "I found it light." T7: "The more questions you solve in mathematics, the more your intelligence improves. There are many questions in the book; but there could be more." T8: "I liked it. I was able to use it effectively. The Module 3 is more focused on the reading skill. We answered the questions correctly. I liked it, used it effectively; we did extra activities." 


\subsection{Findings Related to the Teachers' Opinions about the Applicability of the Source Book Prepared for RPPS}

In order to find an answer to the seventh research question, the teachers' opinions were asked about the applicability of the source book prepared for RPPS and the findings obtained from these opinions are presented in Table 9.

Table 9: Findings related to the Teachers' Opinions about the Applicability of the Source Book Prepared for RPPS

\begin{tabular}{|l|l|c|c|}
\hline Themes & Codes & $\mathbf{n}$ & Teacher Codes \\
\hline \multirow{3}{*}{$\begin{array}{l}\text { Source book of the } \\
\text { Turkish course }\end{array}$} & Applicable & 1 & $\mathrm{~T} 8$ \\
\cline { 2 - 4 } & Partially applicable & 1 & $\mathrm{~T} 3$ \\
\cline { 2 - 4 } & Inapplicable & 4 & $\mathrm{~T} 1, \mathrm{~T} 2, \mathrm{~T} 4, \mathrm{~T} 6$ \\
\cline { 2 - 4 } & Applicable & 3 & $\mathrm{~T} 4, \mathrm{~T} 5, \mathrm{~T} 7$ \\
\hline \multirow{2}{*}{$\begin{array}{l}\text { Source book of the } \\
\text { mathematics course }\end{array}$} & Partially applicable & 2 & $\mathrm{~T} 3$ \\
\cline { 2 - 4 } & Inapplicable & $\mathrm{T} 1, \mathrm{~T} 2$ \\
\hline
\end{tabular}

As can be seen in Table 9, one of the teachers found the source book prepared for the Turkish course applicable, 1 of them found it partially applicable and 4 of them found it inapplicable. On the other hand, 3 of the teachers found the source book prepared for the mathematics course applicable, 1 of them found it partially applicable and 2 of them found it inapplicable. The teachers' opinions about the applicability of the source book are as follows: T1: "It is not suitable for the Module 3. To tell the truth, I downloaded something from the internet and found some materials from other books. I mostly used the book to give homework to children. I determined the deficiencies of the children and this book was not suitable to study with children not knowing how to read." T2: "They had great difficulties; some got panicked." T3: "Some part of it is applicable while some other is not. I did not use the cut and paste activities at all." T4: "Yes, it was applicable in mathematics. I used it effectively. Sometimes, I used supplementary materials but generally I used the book in mathematics. The math book was really good. It was suitable for their level. The Module 3 in Turkish was heavy for children. I tried to study it in the class but the responses of the children were negative, so I decided to use supplementary materials. Not the texts but activities were heavy for children. T5: "I experienced no problem. The book was highly clear and understandable. It was even clearer than the books we used in mainstream classes." T6: "I generally found reading comprehension texts; we read these texts; we answered the comprehension questions; I had to use extra materials." T7: "It was applicable; they did some parts of the book even I didn't tell them to do them. They did the activities easily; they used the book effectively; it was highly applicable." T8: "It was applicable. We used it effectively. There were some words they could not understand in some of the texts. It was highly normal; each student can encounter unknown words in texts. They solved such problems by asking for help from me or through dictionaries. " 


\subsection{Findings Related to the Teachers' Opinions about the Place and Time of Implementation of RPPS}

In order to find an answer to the eighth research question, the teachers were asked their opinions about the place and time of implementation of RPPS and the findings obtained from these opinions are presented in Table 10.

Table 10: Findings related to the Teachers' Opinions about the Place and Time of Implementation of RPPS

\begin{tabular}{|l|l|l|c|}
\hline Themes & Codes & $\mathbf{n}$ & Teacher Codes \\
\hline Class as the implementation place of RPPS & Suitable & 8 & T1, T2, T3, T4, T5, T6, T7, T8 \\
\hline \multirow{2}{*}{ Weekdays as the implementation time of RPPS } & Suitable & 4 & T4, T6, T7, T8 \\
\cline { 2 - 4 } & Unsuitable & 4 & T1, T2, T3, T5 \\
\hline
\end{tabular}

As can be seen in Table 10, all the participating teachers found the class suitable as the place of implementation of RPPS and they expressed different opinions about the time of its implementation. While 4 of the teachers found weekdays suitable for the implementation of RPPS, 4 teachers did not find it suitable.

The teachers' opinions about the time of implementation are given as follows: T1: "Negative, I think. I am also against conducting extra studies with students. There should not be extra lessons rather students should be allowed to relieve. RPPS is like normal school lessons in fact." T2: "I did not experience any problem because I taught two class hours on a weekday. We did the remaining 6 class hours on Saturday at the weekend." T3: "School is good as a place of implementation; you cannot do it at home because it is not one-to-one tutoring. School is the correct place to do it. As the time of implementation, I think weekdays are not suitable." T4: "I prepared my own schedule through coordination with the school administration and the other teachers." T5: "I implemented the program in my classroom. To tell the truth, RPPS does not have any benefits to teachers. On the contrary, it is quite backbreaking; incredibly backbreaking because you teach the same subject for 3 or 4 hours; after you have finished 6 class hours of teaching, you go to teach in this program for two class hours more. These children have some problems in having breakfast. These children do not have breakfast; they just eat a sandwich throughout the whole day; thus, they feel psychologically and physically exhausted towards the end of the day. I do not know whether I would be willing to teach in this program, if it was at the weekend because I have my own private life, my family, a little child; thus, I would not be willing to be a part of this program." T6: "The place of implementation is good. If the lessons were at the weekend, neither teachers nor students would take part in the program." T7: "This is the correct time. I am working hard on weekdays and it would be too difficult for me to work at the weekends; children also need to spend time doing sports or walking around at the weekend." T8: "The place is suitable. We did it after the school. The time of implementation of the program after the school is quite good."

\section{Discussion, Results and Suggestions}

RPPS, which was implemented as a pilot for the first time in the 2017 - 2018 school year, was then expanded to include the whole country in the 2018 - 2019 school year. It was 
first started with the participation of $3^{\text {rd }}$ and $4^{\text {th }}$ graders selected through the application of Student Determination Tools. This program was carried out in order to identify the students who could not achieve the objectives of the current curriculum implemented in mainstream classes and to help these students to overcome their deficiencies so that they could catch up with the official curriculum. Starting from the 2019-2020 school year, the remedial program was started to be administered to only $3^{\text {rd }}$ graders, excluding $4^{\text {th }}$ graders. On the basis of of the opinions elicited through the questions asked to the teachers about the program, it was intended to conduct a comprehensive evaluation of the program, to elicit the experiences of the teachers lived before, during and after the implementation of the program, and to shed light on how to reduce the potential problems to be experienced when the program continues.

The teachers participating in the interviews about RPPS evaluated RPPS as a program that was put into effect with the idea that there should not be any students behind the curriculum and defended the accuracy and usefulness of this idea. In the existing research, the general goals of RPPS have been seen as positive in terms of the effort to create a permanent effect by eliminating the learning deficiencies, and to ensure equal opportunity among students (Cesur and Yetkiner, 2020; Kırnık, Susam and Özbek, 2019; Sarıdoğan, 2019; Toptaş and Karaca, 2019). According to the TEDMEM report (2020), trying to eliminate learning deficiencies with the intervention made in the early years is important for both individual and social attainments. The students' feeling of failure, repeating the class, remaining below the class level may create adversities in their lives and cause them to leave formal education. In addition, in order to ensure full equality of opportunity in education, necessary arrangements should be made in schools where double sessions are conducted, whose students are transported to school from distant areas and back, and which have multigrade classes, and every needy student should benefit from this program.

Teachers think that the program is not well structured and do not consider it appropriate to combine $3^{\text {rd }}$ and $4^{\text {th }}$ grade students in same classes. Students' being taught in the same module although they have different levels of achievement was seen to be a problem. In the 2019-2020 school year, RPPS was started to be implemented to only $3^{\text {rd }}$ graders. In this way, the problem of multigrade classes was eliminated. However, many of the teachers stated that RPPS should be started from the $2^{\text {nd }}$ grade onwards. The earlier the learning deficiencies are diagnosed, the earlier intervention can be made. In this process, the sense of learned helplessness, if any, can be eliminated for students. In addition, lagging behind their grade level can distract students from the educational environment. The remedial program aims to help students to catch up with the curriculum followed in mainstream classes. Teachers stated that students could lag behind at every level, they evaluated the philosophy of this program positively, but emphasized that it should not be restricted with certain time limits rather it should have continuity. In other studies, conducted on teachers (Cesur and Yetkiner, 2020; Balantekin, 2020; Demirel, 2020), similar findings have been reported in general and there seems to be a general consensus on starting the program from the $2^{\text {nd }}$ grade. It is also suggested 
that more fine-tuned measurements should be used in the determination of the levels of students to be included in the same module and the number of modules should be increased if necessary.

Teachers see not knowing the reason why these students cannot learn as a problem. As some students to be normally included in the Individualized Education Program (IEP) by diagnosing with different means are included in this program, teachers criticised this aspect of the program. They stated that the counselling teachers did not do enough studies on this subject, they did not give the necessary support and the parents did not want their children to be diagnosed. Both teachers and parents need more information about RPPS and IEP. It should be emphasized that these prepared programs ensure that students are protected within the system, and that they are supported by the state free of charge to overcome their deficiencies. After the needs of the student are determined, it is beneficial to take the measures required to meet these needs. Students should be explained that the shortcomings of these years will be constantly encountered in both other levels of education and life skills, and necessary studies should be carried out on the importance and sensitivity of this issue.

The fact that RPPS is not compatible with the currently implemented curriculum in mainstream classes caused difficulties for teachers. Students' seeing different topics in RPPS and studying different topics in the classroom environment caused confusion for both students and teachers. Therefore, it would be more suitable for RPPS to progress in compliance with the curriculum. In the first weeks when the school is opened, steps such as determining needs, forming classes, selecting teachers should be taken immediately. It will be beneficial if the commissions established on this issue tighten their inspections and minimize the problems in the calendar prepared for RPPS.

Teachers stated that when the number of students in the classroom is low, the program will be carried out more effectively. It was also emphasized that teachers should work with students having learning deficiencies more individually. Similarly, Çaycı and Demir (2016) found in their studies that more positive results were obtained when students were given one-on-one attention, and it became difficult to reach the desired result in crowded classes. In the study, the teachers stated that the students participating in the program had behavioural problems as well as instructional problems, so they had problems when they came together and therefore the class sizes should be reduced. Teachers' unwillingness to take part in the program led to the higher number of students in classes. The reason for teachers' unwillingness to take part in the program is that they are paid little for the classes they teach in the program and that they do not want to stay at school for extra 6 hours on weekdays. In addition, as the parents of some students were working and some students could not come to the school because of transportation problems, they did not attend the program. Some teachers argued that if the program were implemented at the weekend, fewer teachers and students would be willing to participate in the program. Such problems caused more student absenteeism. Students' absenteeism increased and active participation in lessons decreased because of the reasons such as the time of the classes, seasonal diseases, students' feeling exhausted after 
six class hours in mainstream classes. Lack of interest and indifference on the part of families caused problems. During the lessons of the program, students felt various needs such as eating, resting playing and teachers occasionally confronted with parents. In the interviews, although the teachers stated that the school as the place of implementation of the program is suitable, they expressed different opinions about the time of the implementation of the program. In this regard, the teachers suggested that RPPS should be presented to students by enriching it with the addition of different courses and at the weekend when necessary, and that some precautions should be taken against the problems such as exhaustion, boredom and hunger of students.

In the implementation of the program, the opinions of the implementers, their experiences in the stages of the implementation of the program, their views of the program and the way they implement the program are important. No matter how detailed the programs are prepared, the outcome varies depending on the implementer's attitude, opinion, method of implementation, and whether he/she values the program. The teachers stated that they did not receive any in-service training about the program. Few teachers stated that meetings were held by the school administration and in these meetings, the main focus was on the determination of the teachers who would take part in the program. Some teachers stated that they were not given a guideline and as a result, they conducted the program on the basis of their own professional experiences. Similar results were also reported by Yıldız and Kılıç (2020). A greater importance should be attached to in-service training and informing teachers and teachers should be encouraged to be more committed to the program by sharing more details with them.

When the objectives of RPPS were evaluated, negative feedbacks were received from teachers about the mathematics course. In general, the teachers evaluated the objectives as inadequate. On the other hand, their opinions about the source book are positive in general. Toptaş and Karaca (2019) evaluated the opinions of class teachers delivering math classes in RPPS and found that the teachers think that objectives and activities in the mathematics textbook are suitable for the target audience. As for the Turkish course, Kirnık, Susam and Özbek (2019) reported findings similar to the findings of the current study. The teachers stated that the program progressed too fast, and the subjects focused on grammar, reading and reading comprehension were inadequate. Particular emphasis was put on the necessity of including more reading and reading comprehension activities in the program. The teachers found the source book used for the Turkish course inadequate and its content too heavy in general. Particularly, the content of the Module 3 was found to be too heavy. Moreover, they stated that the number of activities is inadequate and suggested that more activities should be included on grammar so that the content of the book can be made more applicable.

Primary education refers to a period in which people acquire the basic skills they will need through the rest of their lives. Acquisition of skills such as reading and writing skills, listening and reading comprehension skills, verbal expression skill, four operations skill, skill of deciding whether a situation encountered is a problem and problem solving skill increases efficiency in life. In light of the results of the current study, it can be 
suggested that RPPS should be continued, that the grade restrictions to the implementation of the program should be removed rather the program should be offered at any grade level if needed, that the program can be offered by enriching it with different courses and at the weekend when needed, that teachers should be informed more about the program, that some flexibility should be provided for teachers in the implementation of the program and that the applicability of the source books used in the program should be increased.

\section{Conflict of Interest Statement}

The authors declare no conflicts of interests.

\section{About the Author}

Sevgi Balkan is working as a class teacher in the city of İstanbul. At the same time, she is a student at the Elementary Teaching PhD Program of the Graduate Education Institute of İstanbul University- Cerrahpaşa.

Coşkun Küçüktepe is working as an Associate Professor in the Department of Curriculum and Instruction in the Hasan Ali Yücel Education Faculty of İstanbul University- Cerrahpaşa.

\section{References}

Balantekin, Y. 2020. İlkokullarda Yetiştirme Programı (İYEP) Türkçe Dersinin Öğretmen Görüşlerine Göre Değerlendirilmesi: Bir Karma Yöntem Araştırması. Türk Eğitim Bilimleri Dergisi, Cilt 18 (1): 153 - 184.

Cesur, B., Yetkiner, A. 2020. İlkokullarda Yetiştirme Programı (İYEP) Hakkında Öğretmen Görüşlerinin Belirlenmesi. Başkent Üniversitesi Journal of Education, 7(2): 375 - 392.

Çaycl, B., Demir, M. K. 2006. Okuma ve Anlama Sorunu Olan Öğrenciler Üzerine Karşılaştırmalı Bir Çalışma. Türk Eğitim Bilimleri Dergisi, 4(4), 437 - 456.

Gençoğlu, C. 2019. Milli Bir Destekleme ve Yetiştirme Sistemi Modeli: İlkokullarda Yetiştirme Programı (İYEP) Derleme Makalesi. Milli Eğitim Dergisi Cilt 48(1): 853 $-881$.

Demirel, H. 2020. İlkokullarda Yetiştirme Programına Yönelik Öğretmen Görüşleri. Pamukkale Üniversitesi Eğitim Bilimleri Enstitüsü, Eğitim Bilimleri Anabilim Dalı Eğitim Yönetimi, Teftişi, Planlaması ve Ekonomisi Bilim Dalı, Tezsiz Yüksek Lisans Projesi. Denizli.

Dilekçi, Ü. 2019. İlkokullarda Yetiştirme Programına (İYEP) İlişkin Öğretmen Görüşleri. Milli Eğitim Dergisi Cilt 48 (1): 433 - 454.

Kırnık, D., Susam E., Özbek R. 2019. İYEP (İlkokularda Yetiştirme Programı) Uygulamalarına İlişkin sınıf Öğretmenlerinin Görüşleri. Milli Eğitim Dergisi, 48(1): $387-415$ 
MEB. 2018. İlkokullarda Yetiştirme Program Yönergesi. 07.02.2018 tarihinde https://tegm.meb.gov.tr/meb ivs dosvalar/2019 09/05171730 YYEP Yonerge.pd f adresinden alınmıştır.

MEB 2019. İlkokullarda Yetiştirme Programı Uygulama Kılavuzu. 15.12.2019 tarihinde https://tegm.meb.gov.tr/meb iys dosyalar/2019 10/01150934 YYEP UYGULAMA KILAVU ZU.pdf

Merriam, S., B. 2015. Nitel Araştırma Desen ve Uygulama İçin Bir Rehber. Çev. Ed. Prof. Dr. Selahattin Turan, Nobel Akademik Yayıncılık, 3. Basımdan Çeviri, Ankara.

Sarıdoğan, E. 2019. İlkokullarda Yetiştirme Programı'nın 3. ve 4. Sınıf Öğrencilerinin Başarılarına Etkisi. Aydın Adnan Menderes Üniversitesi, Sosyal Bilimler Enstitüsü Eğitim Bilimleri Anabilim Dalı, Yüksek Lisans Tezi. Aydın.

TEDMEM. 2020. 2019 Eğitim Değerlendirme Raporu (TEDMEM Değerlendirme Dizisi 6). Ankara: Türk Eğitim Derneği. https://tedmem.org/download/2019-egitimdegerlendirme-raporu?wpdmdl=3403\&refresh=5f8f2168833691603215720 adresinden 16.06.2020 tarihinde alınmıştır.

Toptaş, V.; Karaca, E., T. 2019. İlkokullarda Yetiştirme Programı (İYEP) Kapsamında Matematik Derslerini Yürüten Sınıf Öğretmenlerinin Görüşlerinin İncelenmesi. Milli Eğitim Dergisi 48(1): 417 - 431.

Woolfolk, A. 2015. Eğitim Psikolojisi. Çev. Duygu Özen, Kaknüs Yayınları, 1. Basım, İstanbul. Yıldırım, A.; Şimşek, H. 2018 Sosyal Bilimlerde Nitel Araştırma Yöntemleri. Seçkin Yayıncılık, 11. Baskı, Ankara.

Yıldız, V., A.; Kılıç, D. 2020. İlkokullarda Yetiştirme Programı (İYEP) Kurs Sürecinin Öğretmen Görüşlerine Göre Değerlendirilmesi. Turkish Studies Education, 15(2): 1399 - 1410. 
Creative Commons licensing terms

Authors will retain the copyright of their published articles agreeing that a Creative Commons Attribution 4.0 International License (CC BY 4.0) terms will be applied to their work. Under the terms of this license, no permission is required from the author(s) or publisher for members of the community to copy, distribute, transmit or adapt the article content, providing a proper, prominent and unambiguous attribution to the authors in a manner that makes clear that the materials are being reused under permission of a Creative Commons License. Views, opinions and conclusions expressed in this research article are views, opinions and conclusions of the author(s). Open Access Publishing Group and European Journal of Alternative Education Studies shall not be responsible or answerable for any loss, damage or liability caused in relation to/arising out of conflict of interests, copyright violations and inappropriate or inaccurate use of any kind content related or integrated on the research work. All the published works are meeting the Open Access Publishing requirements and can be freely accessed, shared, modified, distributed and used in educational, commercial and non-commercial purposes under a Creative Commons Attribution 4.0 International License (CC BY 4.0). 